UDK: 28:929 Smajlović A.

Primljeno: 24.4.2019.

Prihvaćeno za štampu: 31.5.2019.

dr.sci. Halil Mehtić, vanredni profesor

Islamski pedagoški fakultet

Univerzitet u Zenici

halilmebti@@hotmail.com

\title{
SJEĆANJE NA RAHMETLI, PROF. DR. AHMEDA SMAJLOVIĆA
}

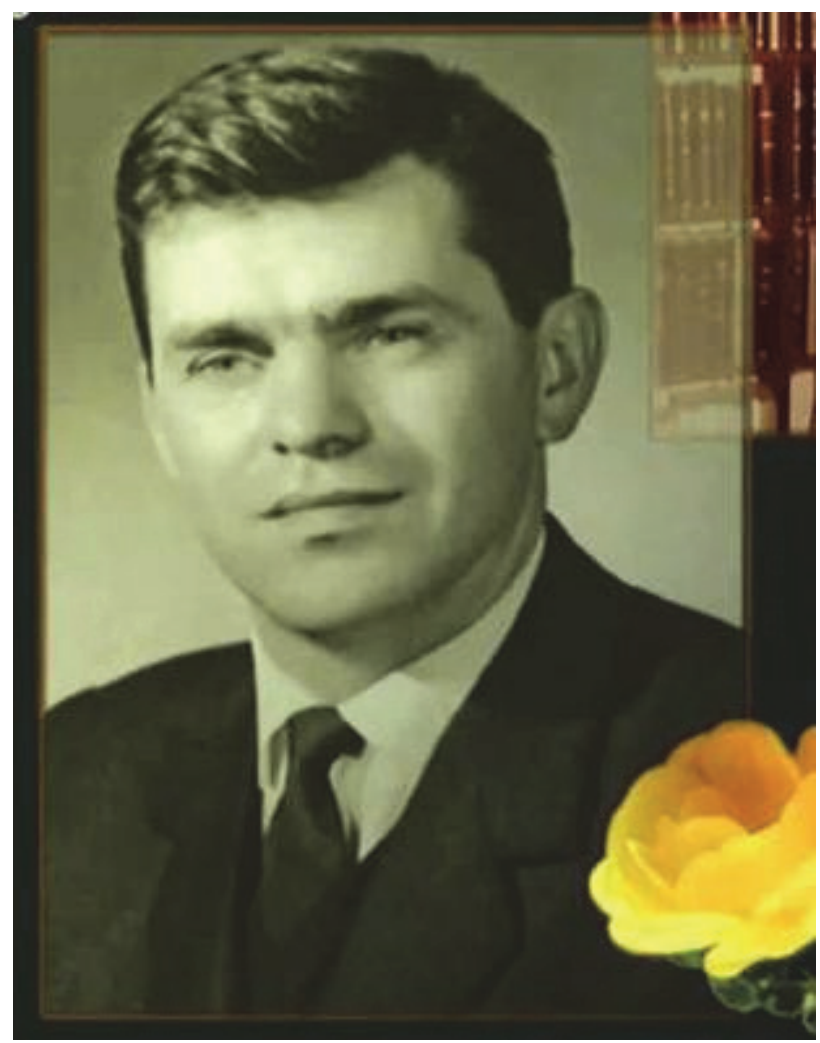




\section{Sažetak}

Prof. dr. Ahmed Smajlovic, bez sumnje, ubraja se među najistaknutije bošnjačce alime, od odlaska turske uprave pa sve do naših dana. Kao prvi doktor nauka, na jednom od arapskih univerziteta, bio je pravo obogaćenje za Islamsku zajednicu, BiH, kao i svih muslimana koji su živjeli u bivsoj SFRJ. U ulozi predsjednika Starjesinstva Islamske zajednice za BiH, Hrvatsku i Sloveniju i profesora na Islamskom teološkom fakultetu u Srajevu, dao je nemjerljiv doprinos unapredenju i osavremenjivanju rada IZ, kao i razvoju i sirenju ideje islama, kako na domaćoj sceni tako $i$ izvan granica naše domovine. Uzme li se u obzir da je dr. Ahmed Smajlović radio u vrijeme najizraženijeg totalitarnog socijalističkog režima, ne možemo a da ne izrazimo svoje veliko postovanje $i$ zahvalnost, za sve što je uradio, utoliko prije što se državni agresivni ateizam nastojao sve više proširiti, a visokomisleći ljudi našeg naroda osujetiti u njihovim vjerskim i nacionalnim nastojanjima.

\section{Uvod}

Jedanaestog augusta 2018. godine navršilo se trideset godina od preseljenja na Ahiret našeg poštovanog profesora dr. Ahmeda Smajlovića. Valorizirajući njegov radni angažman, sa ovovremene distance, možemo objektivno donositi sud o tom iznimnom bošnjačkom alimu, koji je načinio prekretnicu u radu Islamske zajednice u cijelosti. Većinu aktivnosti kojima se bavila Islamska zajednica ili se još uvijek bavi, koje su glavno obilježje njenoga rada, vezano je za ime dr. Smajlovića. Svi objektivni promatrači njegovog rada, a posebno njegovi saradnici, posvjedočit će njegovu historijsku ulogu u konsolidaciji Islamske zajednice i razvoju vjerskog života na našim prostorima pa $\mathrm{i}$ šire. Njegovim dolaskom na mjesto predsjednika Starješinstva Islamske zajednice BiH, Hrvatske i Slovenije, pokreću se brojne aktivnosti koje su rezultirale pozitivne efekte na sveukupni rad i status Islamske zajednice u tim republikama. Uz sve to krasilo ga je nastojanje osavremenjivanja rada Zajednice kao i pokušaj savremenog tumačenja šerijatskih propisa shodno potrebama vremena i prilika u kojima su živjeli muslimani. 


\section{Rođenje i školovanje}

Profesor dr. Ahmed ef. Smajlović rođen je 1938. godine, kao sedmo dijete porodice Smajlović, u srebreničkom selu Tokoljaci, u porodici u kojoj je njegovan ilum i vjera. Prve spoznaje o islamu usvojio je od oca Ali efendije, da bi se kao dječak, nakon završenog četvrtog razreda osnovne škole, 1950. godine obreo u Sarajevu, u Gazi Husrev-begovu medresu, koju je završio 1958. godine. Bio je jedan od najuspješnijih učenika G.H. medrese od njenog osnutka do danas.

U nastojanju tadašnjeg reis-ul-uleme, Sulejmana ef. Kemure, da osnaži rad Islamske zajednice što kvalitetnijim kadrom, odlučeno je da Ahmed Smajlović 19. oktobra 1962. godine, u prvoj poslijeratnoj generaciji studenata Islamske zajednice u Jugoslaviji, svoje interesovanje za naukom nastavi na islamskom univerzitetu Al-Azhar u Kairu. Na univerzitetu Al-Azhar 1968. diplomira arapski jezik i književnost, nakon čega nastavlja dalje obrazovanje upisivanjem magistarskog studija na istom univerzitetu, gdje 1970. godine magistrira na temu: Muhammed 'Abduhu $i$ njegov uticaj na modernu književnost $i$ renesansu. Jedan je od rijetkih bosansko-hercegovačkih studenata koji sva tri ciklusa visokoškolskog obrazovanja završio u Kairu gdje je 1974. godine odbranio doktorsku disertaciju pod naslovom "Felsefetul istišrâk ve eseruhâ fîl edebil 'arebîjji 1 mu'âsiri" (Filozofija orijentalizma i njen utjecaj na savremenu arapsku književnost) koja je od tada u arapskom svijetu doživjela dva izdanja.

Djelo je štampano na arapskom jeziku i broji 778 stranica. Predstavlja dragocjenost u toj naučnoj oblasti i nezaobilazan je naučni izvor za istaraživače. U uvodnoj riječi, renomirani egipatski publicista, Mustafa Mahmud, s uvažavanjem i riječima hvale, govori o autoru, navodeći da je pisac, do okončanja doktorske disertacije, koristio preko šest stotina izvora (dijela iz različitih naučnih oblasti). Bio je prvi doktor nauka u Islamskoj zajednici. Njegova štampana disertacija toliko ga je učinila poznatim među intelektualnom elitom arapskog svijeta, da kada u tim krugovima kažete da ste iz $\mathrm{BiH}$, (odnosno Jugoslavije) prvo pitanje je: „Poznajete li dr. Ahmeda Smajlovića?“

Dok je boravio u Egiptu, Ahmed Smajlović je bio i predavač na Jugoslavenskoj dopunskoj školi u Egiptu gdje je predavao sociologiju, filozofiju i logiku. Proveo je pet godina na čelu te ustanove, kao njen 
direktor. Zahvaljujući tome kao i njegovom dvanaestogodišnjem boravku u Kairu, dr. Ahmed Smajlović, održavao je kontakte sa istaknutim kulturnim, javnim i naučnim radnicima Egipta i islamskog svijeta.

\section{Radni angažman}

Po povratku u $\mathrm{BiH}$ (1975. godine) radi kao savjetnik reis-ul-uleme za bivšu Jugoslaviju, a potom, 22.marta 1975. godine biva izabran, od strane Vrhovnog sabora Islamske zajednice SFRJ, za predsjednika Starješinstva za BiH, Hrvatsku i Sloveniju. Radeći na tom položaju, dr. Smajlović, rahmetullahi alejhi, bio je pravo osvježenje, generator svih pozitivnih procesa, ličnost koja je svojim autoritetom i znanjem pokrenula tromi mehanizam Islamske zajednice.

Uz to reorganizira službe Starješinstva, što rezultira efikasnijim djelovanjem svih zaposlenih, a samim time i svih organa Islamske zajednice. Izuzetan doprinos, u to vrijeme, dale su službe za vjerskoprosvjetni rad, pravna služba i služba za izdavačku djelatnost, pri kojoj je kasnije osnovana izadavačka kuća El-Kalem, koja i danas uspješno radi štampajući i distribuirajući mnoga korisna djela iz oblasti naše islamske duhovnosti.

Veliku pažnju poklanjao je pisanoj riječi. Pokrenuo je 1. decembra 1978. godine časopis Islamska misao. Bio je urednik prvih sedamnaest brojeva nakon čega su ga zamijenili kasniji profesori na Fakultetu islamskih nauka, Mesud Hafizović, potom Ismet Bušatlić, a nakon njega, Enes Karić i Šefik Kurdić. Časopis je bio prvorazredno štivo posebno dobro prihvaćen u bošnjačkim intelektualnim krugovima. Svojim originalnim radovima i prijevodima sa arapskog jezika, dr. Smajlović je dao značajan doprinos obogaćenju štiva časopisa i njegovoj sveukupnoj afirmaciji.

Posebnu pažnju poklanjao je radu sa islamskim pregaocima na terenu, prije svega imamima. Ostaće upamćeni stručni seminari koji su održavani u Sarajevu i drugim mjestima $\mathrm{BiH}$, a posebno seminar koji je održan u Sarajevu 1980. godine, na kojem su predavači bili najistaknutiji alimi iz Egipta, Saudi Arabije, Alžira i Tunisa. Tom prilikom, predstavnici Islamske svjetske organizacije Rabita, 
učesnicima seminara podijelili su kapitalna djela iz raznih naučnih disciplina.

Njegova učenost i popularnost priskrbili su mu članstvo u mnogim međunarodnim islamskim organizacijama u Evropi i svijetu. Bio je učesnik brojnih konferencija, simpozijuma i stručnih savjetovanja, na kojima su njegovi referati i diskusije pobuđivali posebnu pažnju. Bio je dostojan predstavnik Islamske zajednice i muslimana bivše SFRJ i zastupnik istine o stvarnom položaju muslimana u tadašnjoj Jugoslaviji. $\mathrm{Za}$ doprinos unapređenju odnosa Islamske zajednice sa širom društvenom zajednicom, kao i za doprinos razvoju međureligijske tolerancije i dijaloga, dr. Ahmed Smajlović je, ukazom Predsjedništva SFRJ br. 84 od 30 septembra 1981. godine, odlikovan Ordenom zasluga za narod sa srebrenom zvijezdom.

Profesora Smajlovića krasila je izuzetna energija i entuzijazam. O tome svjedoče stotine održanih predavanja i vazova širom $\mathrm{BiH}$ i bivše Jugoslavije, prisustvovanje brojnim otvorenjima džamija, posjete medžlisima IZ i susreti sa džematlijama, sastanci i prijemi u općinskim i republičkim komisijama za odnose sa vjerskim zajednicama, sastanci sa saradnicima iz raznih institucija i zavoda, stotine ispisanih stranica u glasilima Islamske zajednice: Preporod, Glasnik,Takvim i Islamska misao i nadasve rad sa studentima Islamskog teološkog fakulteta. Jednostavno rečeno, dr. Ahmed Smajlović je na svim područjima svog pregalačkog rada ostavio neizbrisive tragove na polju imamskomuallimske, oratorske, prevodilačke i naučne djelatnosti.

Dr. Ahmed ef. Smajlović je posebno zaslužan za otvaranje ženskog dijela G.H. medrese u Sarajevu, Zagrebačke džamije, mesdžida u Ljubljani, Puli, Splitu i Osijeku. Njemu pripadaju zasluge i za unapređenje organizacije odlaska na hadždž, akcije klanja kurbana, uređenja ekonomije G.H. medrese na Jarčedolima, organiziranje masovnog prikupljanja i otkupa kurbanskih kožica. Posebnu brigu i interes pokazivao je za gradnju, sanaciju i restauraciju vjerskih objekata. Zbog velikog doprinosa $\mathrm{u}$ izgradnji Islamskog centra $\mathrm{u}$ Zagrebu današnja Islamska gimnazija, a ranije medresa, nosi njegovo ime. 


\section{Rad na Islamskom teološkom fakultetu}

Od samog početka rada Islamskog teološkog fakulteta, (1977.godine) angažovan je, u zvanju vanrednog profesora, na predmetima Akaid (islamsko vjerovanje) i Islamska filozofija. U martu 1985. godine, dr. Smajlović, na ITF-u, zbog svih zakulisnih radnji koje su se odvijale oko njega, zasniva stalni radni odnos gdje ubrzo biva izabran za redovnog profesora. Tokom stalnog angažmana na Fakultetu, maksimalno se posvetio predavanjima i svom naučnom radu. On nije samo vodio i održavao svoju Katedru na potrebnom nivou, već je nesebičnim zalaganjem učestvovao u podizanju , konsolidaciji i preoblikovanju cjelokupne naučne fizionomije i reputacije ITF-a. Kao njegov student, imao sam priliku uvjeriti se $\mathrm{u}$ sve to, a posebno s koliko dobrote $\mathrm{i}$ očinske topline se odnosio prema nama studentima. Mi koji smo imali čast biti njegovi studenti, oduševljavali smo se njegovim predavanjima, a posebno navođenjem literature $\mathrm{i}$ autora koja su vezana za meteriju koju je izlagao. U želji da afirmira Islamski teološki fakultet i nas kao prvu generaciju studenata, pokrenuo je u Carevoj džamiji Kjurs tribinu gdje smo, kao studenti, izlagali svoje seminarske radove iz akaida, što je u masama pobudilo veliko interesovanje i postiglo zapažene efekte. Iza sebe je ostavio brojne svršenike ITF-a, koji su kasnije postali istaknuti naučni i javni radnici, kao što su: Ismet Bušatlić, Rešid Hafizović, Enes Karić, Adnan Silajdžić, Hasan Čengić, Šefik Kurdić, Izet Terzić, Ismail Bardi, Hasan Džilo i mnogi drugi.

U očima običnog svijeta, dr. Ahmed ef. Smajlović uživao je posebne simpatije. Bio je nezamjenjiv gost na velikim vjerskim skupovima gdje je kao vaiz napajao vjerničke duše, kazujući o ljepotama i savršrnosti Allahovog dina. Sarajlije se i danas živo sjećaju njegovih hutbi u Carevoj džamiji i ramazanskih dersova u Begovoj džamiji, na koje su dolazili mnogi muslimani i iz drugih bosansko-hercegovačkih mjesta.

\section{Njegov spisateljski opus}

Iako je živio relativno kratko ipak je za vrijeme svog životnog vijeka objavio 260 radova koji svojim obimom prelaze pet hiljada stranica. Njegovo najpoznatije i najobimnije djelo je "Felsefetul istišrâk ve eseruhâ fîl edebil 'arebîjji 1 mu'âsiri" (Filozofija orijentalizma i njen utjecaj na savremenu arapsku književnost), objavljeno na arapskom jeziku. Na bosanski jezik, između ostalog, preveo je i objavio od dr. 
Mustafe Mahmuda, Dijalog s prijateljem, od Rože Garodija, Islam kultura i socijalizam, od Ebu Vefa Taftazanija, Filozofija Ihvanus- safa i njihov doprinos islamskoj filozofskoj misli, od dr. 'Abdulaziza Kamila, Islam $i$ rasna diskriminacija, od dr. Ibrahima Makdura, Islamkoarapski utjecaj na evropsku renesansu na polju filozofije, Dijalog islamskih $i$ evropskih naučnika, od dr. Muhammeda Halefullaha Ahmeda, Islamsko-arapski utjecaj na evropsku renesansu, od dr. Muhammeda el-Behija, Ahmed bin Tejmijje, Muhammed bin 'Abdulvehhab i Muhammed bin Ali es-Senusi. Također je preveo od Ebul-Dža'fera et-Tahavija, Tahavijev akaid, od Imama Ebul-Hasana elEš’arija, Vjerovanje ehlus-sunneta, ehlul-hadisa $i$ ehlus-selefa, od Dželaludina es-Sujutija, Nauka o osnovama vjere, od Imama Ahmeda ibn Hanbela, Odgovor džehmijama i zindicima, od Imama Ahmeda bin Tejmijje, Kitabu et-tevhid, od Imama Muhammeda ibn Jusufa esSenusija, Ummul-barahin i mnoge druge. U njegovoj pisanoj zaostavštini ostalo je nekoliko knjiga pripremljenih za štampu od kojih je najznačajnija Historijski razvoj akaidske nauke $i$ njezini glavni predstavnici i Hrestomatija akaidskih tekstova.

Posebno je značajno naglasiti njegov prijevod, sa bosanskog na arapski jezik, romana Derviš $i$ smrt, od Meše Selimovića, za koji se veže interesantna anegdota. Naime, kada je konsultujući se sa Mešom Selimovićem, izlagao dijelove prevedenog romana s namjerom da se uvjeri da li je dobro razumio autorovu poruku, pisac mu je rekao: „Mladiću, pa ti si to razumio bolje nego ja i u prijevodu ponudio jaču poruku nego što je moja."

Dakako, dr. Smajlović je zaslužan i za prvi prijevod na arapski jezik, poznate balade Hasanaginica, s kojom je arapskoj čitalačkoj publici predstavio dio naše kulturne baštine iskazane kroz pisanu riječ. Međutim, njegova doktorska disertacija ostaje njegov najznačajniji spisateljski poduhvat, koja je tek prije nekoliko godina prevedena na bosanski jezik. Dosta pisane građe ostalo je u rukopisu. Na žalost, do danas to niko nije sistematizirao niti objavio. Pisao je na tri jezika: bosanskom, arapskom i engleskom.

\section{Njegovo smjenjivanje i diskreditiranje}

Široka lepeza vjerskih aktivnosti dr. Smajlovića nije mogla proći nezapaženo od strane čuvara komunističkog režima, koji su religiju po 
svaku cijenu htjeli učiniti privatnom stvari i pojavom koja remeti šemu njihovog ateističkog režima. Njegove aktivnost, u velikoj mjeri zasmetale su i određenim krugovima u Islamskoj zajednici, prije svega doušnicima, karijeristima, anarhistima i onima koji se u zdravoj konkurenciji nisu mogli nametati s njim na bilo kom polju djelatnosti IZ-e. U prvo vrijeme ljubomora, a zatim zavist koja se pretvorila $u$ mržnju, rezultirala je neprikrivenim opstrukcijama i radom protiv njega. To su dobrano prepoznali oni iz prvog boljševičkog ešalona i uz pomoć svojih doušnika i nekih sitnih i bolesnih duša iz redova IZ-e, što ih Kur'an časni naziva licemjerima, isplaniraše Zlaću. U tom motelu, nadomak Banovića, 1985. godine su definitivno uokvirene intrige „naših“ i planovi komunističkih vođa za diskreditaciju uzoritog alima. Njegovu smjenu trebalo je u očima javnosti nečim opravdati. U prilog tome izmišljaju dvadesetak tačaka „,nezakonitog“ djelovanja među kojima se našla i tačka sa kojom je Profesor terećen za štampanje njegove doktorske disertacije, na arapskom jeziku, sredstvima Islamske zajednice, a zapravo, njegovu disertaciju, štampala je Rabita. Beskrupulozni karijeristi, optuživali su ga za nešto što je trebalo biti ponos svih nas Bošnjaka. Poznavaoci prilika u društvu i Islamskoj zajednici, kategorični su u uvjerenju da je smjena dr. Ahmeda Smajlovića uslijedila iz dva razloga. Prvi je, što je dr. Smajlović bio nesporni autoritet u Islamskoj zajednici i što su iza njega stajali veliki rezultati, a komunistički režim nije trpio autoritete i lidere koji su mogli povesti široke narodne mase. Drugi razlog je, što je svaki član kao i svaki službenik Islamske zajednice, u njemu vidio budućeg reis-ul ulemu, čime bi još više dobio na utjecaju. To se moglo spriječiti samo njegovom smjenom i njegovim marginaliziranjem.

\section{Kukavičluk njegovih saradnika}

Kako je samo otužno izgledalo rušenje našeg nespornog vjerskog autoriteta, još jadnije je izgledalo ponašanje nas, njegovih poštovaoca, iz svih struktura IZ-e. Poslije njegove dženaze jedan imam je to na slikovit način opisao: "Koliko plačem za rahmetli Ahmedom, toliko plačem nad ovom i ovakvom našom sudbinom..." Brojni imami, predsjednici odbora, profesori Fakulteta i Medrese, službenici Starješinstva koje je on ,uhljebio“, nijemo i iz prikrajka, bojeći se da se njima šta ne desi, pustili su dušmane da trgaju njegovu dušu i 
dostojanstvo kao što čopor hijena trga i savladava nemoćnu žrtvu. Moramo se upitati hoće li nam naš Profesor halaliti to kukavičko držanje, a posebno, hoćemo li imati opravdanje pred Uzvišenim što smo šutjeli kada je trebalo reći istinu i stati uz njega. Kako uspijevaju beskrupulozni karijeristi govore riječi mudrog hazreti Alije, r.a.: "Ne pobjeđuju zagovornici neistine zbog snage svoje laži; oni pobjeđuju zbog popuštanja i malaksalosti istinoljubaca u borbi za istinu."

Godinama prije smjenjivanja nastojali su ga kompromitirati, pripisujući mu djela koja su, zapravo, oni radili. Međutim, on se nije puno branio, radio je misleći da su to pojave prolaznoga karaktera, mada, kao obični smrtnik, nije bio imun na sve to. $U$ vrijeme žestokih insinuacija i pritisaka, požalio se jednom prijatelju, kroz suze mu rekavši: "Ja više ne znam šta da radim. Kada sam kod kuće, komunisti me optužuju za panislamizam i fundamentalizam, a kada sam izvan granica $\mathrm{BiH}$ "naši" iz Islamske zajednice, šalju depeše u arapski svijet, optužujući me da sam komunistički špijun. Toliko puta sam, odmah nakon slijetanja, na aerodromima nekih arapskih zemalja, bio privođen i saslušavan od strane njihovih obavještajnih službi.“ Osnaženi pozicijama koje su brže-bolje zauzeli u Islamskoj zajednici, nakon njegovog smjenjivanja, okuražili su se do te mjere da su ga čak razriješili i dužnosti profesora na ITF-u. Tadašnji reis Mujić, imao je delikatnu zadaću uručenja rješenja o smjeni. Po riječima očevidaca, pripremljeno rješenje mjesecima je držao u ladici stola, ne imavši dovoljno hrabrosti da ga uruči. Nekoliko dana nakon što je i do Profesora doprla vijest o njegovom razrješenju, doživio srčani udar, koji je, bio uzrokom njegove brze smrti.

\section{Dženaza}

Trinaestog augusta, odnosno prvog muharrema 1409. Hidžretske godine, iza podne namaza, u prisustvu velikog broja vjernika, u vječnu kuću ispraćen je naš cijenjeni profesor. Veliki broj ljudi gledao ga je na sofi Begove džamije, ali ovaj put na tabutu.

Ako poslije svega išta može djelovati utješno, onda je to činjenica da su imami, prilikom poznatih okupljanja 1989. god., iznudili od zvaničnika bitne detalje koji su se ticali zakulisnih radnji u vezi s njegovom smjenom. U amfiteatru Gazi Husrev-begove 
medrese, tadašnji reis-ul-ulema, Husejn Mujić, spomenuo je ljude iz Islamske zajednice i državnih struktura koji su režirali i realizirali njegovu smjenu. Taj sramni čin ovjekovječen je i u sklopu profesorove biografije, objavljene u poznatom svjetskom biobibliografskom djelu, na arapskom jeziku, El-Ealam, autora Ez-Ziriklija.

Padom komunizma i dolaskom višepartijskog sistema, a s njim i vjerskih sloboda, često se prisjećamo nekih naših profesora, a posebno dr. Ahmeda Smajlovića i Husejna Đoze, koji bi, zasigurno, blagodat vjerskih sloboda iskoristili višestruko bolje nego što je mi koristimo.

\section{Zaključak}

Prof. dr. Ahmed Smajlović predstavlja paradigmu znastvenika i vjerskog lidera koji je svoj životni vijek i raspložive potencijale uložio za boljitak Islamske zajednice, za afirmiranje ideje islama i za iznalaženje novih rješenja u savremenoj primjeni šerijata. Svojim pregalačkim radom on je želio objediniti tradiciju i savremenost, pomiriti politiku i znanost, pisanu riječ i oratorstvo, rukovođenje Zajednicom i neposrednu djelatnost.

Da je on u tome uspio, možemo posvjedočiti trideset godina nakon njegove smrti. Njegov spisateljski opus, kao i njegov sveukupni angažman na planu afirmiranje islama, nesporno je ugrađen u temelje bosansko-hercegovačke pa i svjetske islamistike. Iako je on u širokim narodnim masama bio poznat kao darovit i uspješan vaiz, njegovo pisano naslijeđe nedvojbeno svjedoči o širini njegove misli i iznimno velikom znanstveniku. Dr. Ahmed Smajlović napisao je stotine tekstova, eseja, komentara iz različitih oblasti islamske znanosti, islamske kulture i civilizacije, tekstove o odnosima Istoka i Zapada, odnosa kršćanskog i muslimanskog svijeta. Također je pisao o fenomenu orijentalizma $i$ njegovim reperkusijama na razvoj savremenog islamskog mišljenja, kako u svijetu tako i kod nas.

Prisjećajući se lika i djela dr. Smajlovića, 2015. godine, naš poznati pisac, Hadžem Hajdarević, za Preporod je napisao: „Godine u kojima je živio i djelovao rahmetli Ahmed ef. Smajlović bile su godine prijelomnice u mnogim aspektima bosanskoga duhovnog, društvenopolitičkog, kulturnog, privrednog života. Ovdašnjem čovjeku je nažalost postalo zazorno čitati znakove vremena. Da su u bošnjačkom 
muslimanskom korpusu izvučene ikolike pouke iz tih i kasnijih vremena, onda bi se, unutar Islamske zajednice i drugih bošnjačkih muslimanskih organiziranosti, barem pokušalo rasvijetliti mnoge tamnine iz te još uvijek bliske prošlosti. Povijest kazuje da se u bosanskim maglama najbolje snalaze hipokrizeri, lažni nacionalni spasioci, ideološke protuhe $\mathrm{s}$ prikrivenim snajperima, trgovci bošnjačkom poviješću i budućnošću. Upravo zbog toga životno i znanstveno djelo rahmetli Ahmeda ef. Smajlovića ostaje i dalje biti zatvoreno i neprotumačeno, i u kontekstu vremena u kojemu je ostvarivano i u kontekstu neizvjesnih, dolazećih vremena.

Sveobuhvatnost njegove ličnosti, slikovito je opisao dr. Mustafa Cerić, rekavši: "Rahmetli dr. Ahmed Smajlović bio je poseban po inkluzivnosti njegova karaktera. On je u svom karakteru imao gotovo sve što je trebalo našoj zajednici - pamet i obraz, ugled i čast, položaj i mjesto u društvu. Ali, iznad svega on je imao vjeru i spoznaju da ljudska duša ako se ne usavršava, neizbježno zapada u grijeh. Njegovo iskustvo više od jedne decenije u Egiptu, gdje se vodila žestoka borba oko statusa Al-Azhara - njegove autonomije i autentične misli, naučilo ga je da vlast i moć nema obzira ni prema kome ni prema čemu što joj stoji na njenom putu. No, to je samo osnažilo njegovo uvjerenje, kojem ga je islam naučio, da nema spasa osim vjere u Boga, odnosno, kao što je dr. Ahmed govorio: "Spas čovječanstva je u pravljenju sebe samoga kao kuranskog čovjeka".

Posebno značenje imale riječi prof. dr. Jusufa Ramića, koji je govorio na rahmetlijinoj dženazi: "Da li smo dr. Ahmedu Smajloviću uzvratili bar djelić zhvalnosti za ono čime nas je zadužio ostaje biti trajnim pitanjem koje će pozadugo kucati na savjesti svih onih koji su bili s njim i oko njega..."

U svakom slučaju, tek sada možemo potpunije osjetiti nedostatak velikog entuzijaste i alima, za kojeg od Milostivog molimo oprost i Džennet-i firdevs.

\section{Korištena literatura i izvori:}

1. Islamska enciklopedija, Mešihat Republike Turske, Istanbul, 2001. godine. 
2. Islamska misao, god. X, broj 116, Starješinstvo Islamske zajednice Bosne i Hercegovine, Hrvatske i Slovenije, Sarajevo, 1998.

3. Jusuf Ramić, Ekskomunikacija i rehabilitacija Ahmeda Smajlovića, Connectum, Sarajevo, 2017.

4. Mahmud el-Arnaut, El-E'alamut-turasi fil-asril-hadisi, Mektebetu daril-urubeti / Daru bin 'Imad, Kuvejt / Bejrut, 2001

5. Muhammed Hajr Ramadan Jusuf, Tetimmetul-ealam liz-Zirikli, 1/27, Bejrut 1998. godine.

6. Novi Horizonti, god. I, broj. 1. Udruženje „Selam“, Zenica, 1999.

7. Zbornik radova Fakulteta islamskih nauka u Sarajevu, Fakultet islamskih nauka u Sarajevu, Sarajevo, 2009. br. 13.

8. http://fin.ba/datoteke/Zbornik13.pdf

9. http://www.zeriislam.com/artikulli.php?id=2587

10. http://www.iltizam.org/tekstovi/read/2307

11. https://www.preporod.com/index.php/svevijesti/magazin/sjecanja/item/4453-sjecanje-na-ahmeda-smajlovica 